\title{
The Borders of Personal and Political: Argumentative Analysis of a (Possible) Sexual Harassment Case in the "\#MeToo Era"1
}

\author{
Veronika Valkovičová
}

\begin{abstract}
Facilitated by the widespread use of the communication tool \#MeToo, the online public space has been opening up to survivor stories and is providing interpersonal emotional support to individuals with experiences of sexual harassment or violence. Witnessing the widespread and collective demand for de-stigmatised survivor-centred and empowering approaches to violence, the scholarly community has been discussing these events as the example of (feminist) counter-publics with counter-narratives, or as the "transformative politics of visibility". This case study contemplates the reactionary forces, focusing on negotiating discursive practices which aim to resist (feminist) counter-narratives in the Slovak online environment. We wish to enrich the existing literature by drawing on the developing scholarship of discourse analysis studies in the "\#MeToo era" and by looking at the argumentative strategies applied by the discussants with regards to one (potential) case of sexual harassment. We do so by proposing to treat the interpretative frameworks of the discussants as stemming from experiences with dominant media narratives, and as being built around the discursive negotiations of "public-private space" and "personalpolitical issues", well-known to feminist theorisations of sexual harassment and violence since the 1970s.
\end{abstract}

KEYWORDS MeToo, sexual harassment, sexual violence, discourse analysis, social media

\section{Introduction}

In October 2018, one year after actress Alyssa Milano prompted her audience to share their experiences with sexual harassment and violence, online searches for the term "\#MeToo" skyrocketed once again. Three years after the discursive events of 2017, \#MeToo has become a common term recognised far beyond the region of its inception. While North American and European feminist and women's rights activism has been engaging in advocacy against sexism and gender inequality (including gender-based violence) for decades, this event marked a turning point in raising awareness, sharing support among wider audiences and

Sociálnístudia/SocialStudies 2/2021.Pp. 125-143.ISSN 1214-813X.https://doi.org/10.5817/SOC2021-2-125

1 The author would like to thank friend and collaborator Zuzana Mad'arová, $\mathrm{PhD}$, for her academic advice and friendly guidance, both of which contributed to this text. The author would also like to thank the two anonymous peer reviewers for their directions and suggestions for present and future research on the "MeToo movement". 
providing a public space for persons with experience of harassment and violence. ${ }^{2}$ While the initial interactions commenced in the "Twittersphere" and at other social media websites (e.g. Facebook and Reddit), the implications of the online discussions also started to gradually appear in offline spaces and communities. Counting the resignations and convictions of perpetrators of sexual violence and harassment and witnessing the changes in organisational cultures of companies across the globe, one would be inclined to posit that the social media discursive events linked to the communication tool \#MeToo provided incentives for a variety of changes (Rihal et al. 2020). Authors studying such online transnational activism also speak of the potential of "localisation" of the movement, as local activist endeavours were able to frame the issue within their national contexts, for example by creating local hashtags such as the French \#BalanceTonPorc, calling out street harassment, the Catholic \#ChurchToo, and the \#MosqueMeToo advocating against the harassment of Muslim women on pilgrimages (Ghadery 2019; Berthet and Kantola 2020; Mishra 2020; Bogen et al. 2020).

Based on the theoretical and critical work of Fraser (1990) and her concept of "subaltern counter publics", Worthington (2020) understands the discursive events connected to \#MeToo as developing (feminist) counter-narratives or even counter-publics to the stigmatising and victim-blaming narratives ${ }^{3}$ on harassment and violence which aim to legitimise and trivialise such practices. This scholarship prompts us to enquire how stigmatising and victim-blaming narratives are negotiated vis-à-vis the popularisation of (feminist) counter-narratives and counter-publics (Enderle 2018) - i.e. how are the acts of intrusion or violence grasped and understood in order to oppose the feminist framing, networked community building and a more complex understanding of gender-based violence?

This particular case study zooms in on an incident of (possible) workplace sexual harassment that was aired and widely discussed in Slovakia. The incident happened in June 2020 and contained sexualised male intrusive behaviour (Vera-Gray 2017) aired as a comedic segment on mainstream Slovak television. The subsequent controversy was assured when both of the protagonists described the gesture as an act of friendship. As it was a rather dubious and ambiguous situation publicly aired to the Slovak audience, this study analyses the discussions under the Facebook posts of two national daily newspapers which aimed to reprimand the male intruder. With the aid of the developing discourse analysis scholarship of sexual violence and harassment in the "\#MeToo era", this case study was interested in

2 In order to follow the legal consensus in the Slovak environment, this paper considers two practices constituting sexual harassment as adopted by European Union standards and the Slovak Anti-discrimination law. These include quid pro quo harassment and hostile environment (Magurová 2008). Since quid pro quo harassment may entail instances of coercion, such practices may involve the criminal offence of sexual violence. Therefore it is not the purpose of this text to theorise or elaborate on the legal differences between sexual harassment and sexual violence as defined by any legal framework. In this text we speak of sexual violence and sexual harassment as separate practices, but we do not wish to insist that they are perfectly separable. Instead, we claim that social reality points to the interconnectedness of these practices.

3 In this text we use two expressions - victim-blaming and survivor-centred narratives - in order to emphasise the empowering framing of the latter, focused on the individual's agency and active negotiation of the situation. 
the reactionary interpretative frameworks and argumentative strategies of the Facebook discussants. While the results reveal a variety of strategies ranging from polarising (Maaranen and Tienari 2020) and trivialising (Lockyer and Savigny 2020) to distracting (Bogen et al. 2019, 2020), other discursive strategies such as recalling "individualised responsibility" (Hindes and Fileborn 2019; Worthington 2020) remind us that the interpretative repertoires of the decades-old feminist scholarship and activism motto "the personal is political" (see e.g. Walby 1990; Gavison 1992; Hansson et al. 2020) continue within hashtag activism (Clark 2016; Suk et al. 2019; Maaranen and Tienari 2020).

The text is structured as follows: first, we present the recent scholarship which has been observing the activist endeavours connected to the discursive events of \#MeToo, and then we move on to the developing discourse analysis scholarship theorising the various discursive practices countering the survivor-centred and feminist narratives. Before presenting the results of the analysis, we contextualise the Slovak case study. The last part of the study is devoted to the findings which are later summarised and discussed.

\section{Transnational Activism of \#MeToo - The Long Awaited Push for Change?}

As a concept, sexual harassment entered the North American and European legal discourse in the 1970s through the influence of the feminist and women's rights social movements, and more persistently in the 1980s. Along with other concepts such as sexism, sex discrimination or "rape culture", the extensive feminist writing and various forms of activism contributed to the development of knowledge and understanding of sexual harassment as an oppressive social practice (McDonald 2012; Reese and Coontz 2018). Feminist theoretical perspectives on sexual violence and harassment during this period were underpinned by emphasis on gendered power structures, as well as the call to address the issue as a public matter (MacKinnon 1979). Complaints of severe male intrusive behaviour as a form of discriminatory practice in employment or education soon appeared, first in the North American courtrooms, and from there in the national media thanks to a number of publicised legal cases (Freedman 2018). ${ }^{4}$ Nevertheless, recalling a notorious statement by the American Psychological Association from 1993, even in the US, sexual harassment seemed to be a "problem with a long past, but a short history" (Rothgerber et al. 2020). Fast forward to nearly three decades later, and the growing public opposition to sexism, harassment and violence is attributable to the possibilities of the interconnected public space of social media, in what is often labelled as the "\#MeToo movement" (Lee and Murdie 2020).

Known to the feminist activist community years before the events of 2017, the motto "Me Too" was first deployed by American activist Tarana Burke, who established her campaign in 2006. Burke, a senior director of the non-profit Girls for Gender Equality, launched the "MeToo" campaign in order to garner solidarity with women and girls of colour who had experienced sexual or intimate-partner abuse, thus stressing the gender-based nature of violence, as well as the intersection of gender and race (Adetiba 2017). In 2017, American

Key court rulings in the US context were issued in cases related to workplace sexual harassment and employers' misconduct in the 1970s and 1980s (e.g. Anita Hill vs. Clerence Thomas). 
actress Alyssa Milano wielded the motto and her influence on Twitter to ask her followers to speak of their own experiences with sexual abuse. Milano received thousands of retweets and replies in the first 24 hours after her post (Enderle 2018). The actress later explained that she was prompted to post the tweet in order to expose Hollywood producer Harvey Weinstein as a person abusing his power and privilege, and a known perpetrator of sexual violence (Enderle 2018). Initiated as an act of "hashtag activism" (Clark 2016; Suk et al. 2019; Maaranen and Tienari 2020), this discursive event was successfully amplified and reproduced with the aid of social media and the hashtag as a tool of communication. While originating in the online environment and taken over by mainstream and international television and press, the advocacy and deployment of discourses on sexual violence and harassment spilled over to offline activist endeavours. In 2017, Time magazine awarded "person of the year" collectively to the advocates of \#MeToo (Rihal et al. 2020).

We approach the online events connected to \#MeToo as discursive events (Jäger and Maier 2013) which were able to assert and popularise new narratives on sexual harassment and violence as social and political issues. Lockyer and Savigny (2020) posit that the discursive events linked to the hashtag as a communication tool allowed for the popularisation of discourses on harassment and violence which were previously known thanks to feminist theorising. These include the recognition of gender-based violence as a power issue, the requirement not to transfer the blame for violence from the perpetrator to the person who experienced harm, and that sexual violence should not be "humourised". But how was this possible with \#MeToo, provided that previous hashtag activist endeavours (e.g. Clarke 2016) were not as successful? Some authors argue that the use of \#MeToo granted international and interpersonal validation to survivors of sexual violence by providing space and potential anonymity to their stories (Enderle 2018; Suk et al. 2019; Rihal et al. 2020; Bogen et al. 2020). The anonymity and vastness of social media platforms such as Twitter or Reddit allowed survivors to disclose their experiences by simply sharing \#MeToo (which stands as a full sentence) while retaining a certain level of privacy, without having to describe their experience and face re-traumatisation (Clark-Parsons 2019; Worthington 2020). Such empowerment was especially facilitated by social media and the so-called "transformative politics of visibility" - advocacy through the visibility of vulnerable groups enabled by the networking of social media (Clark-Parsons 2019; Maaranen and Tienari 2020).

The presence of survivors and the narrations of their experiences in public areas emphasised the everyday yet structural nature of sexual violence as an oppressive social practice (Enderle 2018; Hindes and Fileborn 2019). The advocates were able to stress the need to abandon victim-blaming and propose a supportive and attentive approach to survivors (Enderle 2018; Sanyal 2019). Keeping this in mind, some authors speak of the discursive events of \#MeToo as the popularisation and assertion of "counter-narratives" (Worthington 2020) and networked communities as constituting "counter-publics" (Enderle 2018). Ultimately, \#MeToo as a set of discursive events was important because of its ability to bring a taboo matter condemned to the "private sphere" into the "public" and thus refurbish the discourse which had previously framed violence as individual and private acts (Enderle 2018). As such, sexual harassment and violence were reframed as a complex public matter, with a high 
prevalence and a gendered nature, emphasising, once again as feminist activism would have, that "the personal is political" (Clark-Parsons 2019; Hansson et al. 2020).

While fostering change and providing considerable opportunities, the \#MeToo events have been criticised by feminist activists and scholars who have been wary. Such critiques included accusations of so-called "slacktivism" - a risk-free performance that has little impact since it has no sustained organisational potential (Clark-Parsons 2019; Suk et al. 2019), or the criticism of "call-out culture" and "confession narratives" that push survivors to publicly name the perpetrator, describe the experienced harm and display physical and emotional distress (Sanyal 2019). These narratives push survivors to "confess" their experience of harm and display their trauma in order to be accepted as "worthy survivors" in neoliberal cultures which place individualised responsibility solely upon the survivors (Ghadery 2019). Other authors denounced the practice of "trial by media" which occurred in some countries (Zarkov and Davis 2018).

In the meantime, the events had some impact on a variety of communities and environments around the globe. Among these, we can recall organisational changes to workplace cultures such as those at the European Parliament (Rihal et al. 2020; Berthet and Kantola 2020), or the convictions of some celebrity perpetrators such as Bill Cosby, Harvey Weinstein and Larry Nassar (Suk et al. 2019). "Localised" activist endeavours within and outside of the Global North took to adopting particular hashtags to address local issues (see e.g. Ghadery 2019). But the success of the discursive events cannot be understood without the study of reactionary activism and resisting discourses. Despite the popularisation and amplification of the topic of sexual harassment and violence, initiatives attempting to slander this form of activism abounded. For example, in 2018 a group of well-known French women (including the actress Catherine Deneuve) published an open letter downplaying sexual harassment and violence, opposing the "movement" and describing it as a "totalitarian climate" (Sanyal 2019). Other initiatives denounced the events as "witch-hunts" with an unclear agenda (Ha Rim Rho, Mark, and Mazmanian 2018).

Some scholarship has already been devoted to this topic, as scholars of discourse analysis took to researching the reactive discourses in order to understand how the online narratives on harassment and violence in the "\#MeToo era" come to be constructed and negotiated. The following section presents the recent scholarship while establishing the theoretical basis for the present analysis of the Slovak case study. While the following theorisations are founded primarily in the international and English-speaking realm of the 'Twittersphere', we believe the case study represents a valuable contribution to the scholarly debates.

\section{Countering the Narratives of \#MeToo - Discourses Legitimising and Trivialising Sexual Harassment and Violence}

Quantitative social science researchers have been questioning the beliefs and perceptions related to sexual harassment and violence since the early advocacy endeavours of the women's (feminist) social movements of the Global North in the 1970s and 1980s. A considerable amount of early research looked into the connections between tolerance of violence and harassment and the so-called rape myths/myths of sexual violence (Burt 1980). 
These have been understood as beliefs which aim to deny, legitimise or trivialise sexual violence (Lonsway, Cortina, and Magley 2008). Further behavioural quantitative research carried out over the decades has been interested in the connections between beliefs in rigid gender roles, perceptions of women as sex objects and discourses of masculinities, or so-called anti-feminist beliefs ${ }^{5}$ (see e.g. Konrad and Gutek 1986; Malovich and Stake 1990; Truman, Tokar, and Fischer 1996; Russell and Trigg 2004; McCabe and Hardman 2010).

A different line of qualitative scholarship has been developing vis-à-vis the recent online discursive events whereby scholars seek to understand the discursive practices which are applied to counter the advocacy connected to the \#MeToo. Such scholarship has focused on how individual actors make sense of the events and which argumentative strategies they deploy - i.e. how narratives which trivialise and legitimise harassment and violence are reproduced in speech.

A basic framework was established by Bogen et al. (2019), who approached the online debates of \#MeToo using the framework developed by Ullman (2000) and the Social Reactions Questionnaire. The objective of their research was to study discourses countering survivor-centred narratives of violence, which they described as "negative reactions/ approaches". These can be placed into a number of categories - treating a survivor differently, distracting a survivor from their needs, taking control of the survivors' decisions, blaming the victim, or responding in an egocentric manner. The work of Bogen et al. added three other practices to the former framework established by Ullman - distracting, ego-centric reaction and taking-control.

A different study looked at argumentative strategies which develop trivialising and legitimising narratives of harassment and violence. Studying the Twitter debate over \#MeToo on Wall Street, Maaranen and Tienari (2020) disclosed three such practices:

- Naturalising - gender and gender differences were naturalised as fixed in the anatomy/biology of men and women. In this sense, women were often portrayed as a group "naturally" possessing characteristics that determine the way they are/feel/ act. $^{6}$

- Polarising - the differences between genders are emphasised by creating confrontation. The rhetoric of oppositions and extremes is used to politicise the differences (e.g. by recalling 'feminists' as powerful actors). In creating the differences, hierarchies are implied.

- Humourising - A practice built upon naturalising and polarising which exercises power through the use of humour. Humourising simply constitutes the act of spreading sexualised and demeaning jokes. Humour can be also employed in order to downplay the significance of harassment.

5 According to Truman, Tokar and Fischer (1996), "anti-feminist attitudes" can be understood as beliefs that women should be subordinated to men.

6 While the naturalising of biological dispositions in men was used to justify their actions, naturalising the biological dispositions of women was used to prove women's inability to oppose harassment, or their own sexual desire as the driving force behind harassment. 
Askanius and Møller Hartley (2019) studied the \#MeToo public discourses in Denmark and Sweden by drawing onto the analysis of Rhode (1995). In her work, Rhode came across a variety of argumentative strategies used to respond to "feminist issues". These strategies include marginalisation, personalisation and trivialisation, polarisation of feminists, and depicting feminists as deviants. Polarising may be understood as efforts to make the audience pick sides, one of which is presented as extremely undesirable. In this sense, Askanius and Møller Hartley (2019) also recall a practice which they called rejecting the "culture of offense" (which would be presented as the "extreme side"), or rejection of "excessive political correctness".

Other authors describe a particular strategy which stems from neoliberal and postfeminist thinking, which they characterise as appealing to individualised responsibility (Hindes and Fileborn 2019; Worthington 2020). Discourses on sexual harassment and violence that appeal to such responsibility aim to obscure structural criticism of gender inequality and delegitimise the collective and political nature of advocacy from a particular neoliberal standpoint (De Benedictis, Orgad, and Rottenberg 2019) 7 . The neoliberal concept of individualised responsibility establishes the notion that gender equality has been achieved and therefore the sexual agency of women is not only possible, but also expected. Women are to clearly vocalise their preferences and if they are for any reason unable to, the blame should be nonetheless placed on them (Ghadery 2020). Within this framework, feminist demands are understood as already met and therefore the feminist framing of social issues is viewed as out-dated. The structural nature of gender-based violence is rejected, and since equality has already been achieved, individuals are left to fend for themselves.

Nevertheless, Lee and Murdie (2020) posit that studying the construction and negotiation of discourses on sexual harassment and violence of the "\#MeToo era" in the online environment requires the consideration of the local cultural context, including the possibilities of the political and legal conditions. In order to understand how individuals make sense of and deploy the narratives of harassment and violence, we need to look at the recent developments of the legal framework, as well as the resonance of public discourses, especially those of the mainstream media. In order to see the bigger picture, the next section presents the context and the background of the Slovak case study.

\section{Waiting for a Window of Opportunity? Discourses on Sexual Harassment and Violence in Slovakia}

Sexual harassment and violence as practices of gender-based oppression were first problematised by Slovak feminist and women's rights activism in the 1990s as political issues of "body integrity". The pioneer initiatives of the advocacy civil society sector after the fall

Eschle and Maiguashca (2018) summarise three ways in which "neoliberalism" tends to be conceptualised: by drawing on a historical materialist framework to understand it as a phase of capitalism, by presenting it as a form of Foucauldian governmentality and stressing its individualised market logic, or by looking at it as a technocratic political project driven by a commitment to the free market. 
of the state-socialist authoritarian regime focused on intimate-partner violence (Cviková and Juráňová 2009). In this period, the Slovak feminist publishing house ASPEKT dedicated two whole issues of its magazine to gender-based violence against women and continued to address the topic in its original and translated publications. Other civil society organisations followed and launched trainings, campaigns and various forms of advocacy, as well as the first services aiding survivors of intimate partner violence (Bútorová et al. 2002).

The resonance of the topic promoted by feminist and women's rights activism epistemically and sometimes materially supported by the international community spilled over to the policymaking endeavours of the slowly developing institutions of gender equality policymaking in the late 1990s (Bútorová et al. 2002). The inclusion of sexual harassment into the legal framework became urgent with pressure from the supranational policymaking of the European Union in the pre-accession period of the early 2000s. The transposition pressure in 2008 concluded with the amendment of the Slovak anti-discrimination law (adopted in 2004), which was to later include provisions on sexual harassment. After considerable conservative political backlash and legal disputes, the final version of the legal act defines sexual harassment as a discriminatory practice found in employment, acquisition of goods and services, and education and training (Holubová 2007; Magurová 2008). Despite these endeavours which were launched two decades ago, Slovakia still lacks a clear legal framework that penalises intrusive, sexualised and offensive behaviour occurring in public spaces and on the streets.

While feminist and women's rights advocacy has been debunking rape myths, as well as promoting the framing of sexual harassment and violence as an oppressive gender-based social practice, the mainstream media has been reluctant to adopt such frames. Concerning the period when the aforementioned amendment to the Anti-discrimination Act was passed, the national media were still solely interested in reporting on extreme cases of sexual violence, the tabloid press exploited the stories to monetise them, and women were generally portrayed as helpless victims of violence. The mainstream press and television media also blatantly engaged in cultivating rape myths and their reports unsurprisingly lacked a critical and gendered perspective of violence (Holubová 2010).

While the existing legal framework on equal treatment is quite exceptional with its broad perspective on sexual harassment, both as a quid pro quo and hostile environment (Magurová 2008), the prohibition under law does not necessarily mean high rates of reporting. In the years 2017 and 2018, which were marked by the international uproar of \#MeToo, the Slovak National Centre for Human Rights received only two official complaints (SNSLP 2018, 2019). The latency of sexual harassment and the lack of (publicised) legal cases can be ascribed to the presence of "silence culture" and the widespread belief in stereotypical gender roles, including stereotypes about "aggressive" male and "submissive" female sexuality (Valkovičová and Kuruc 2020).

Despite such significant non-reporting to the public authorities, Slovakia has seen a rise in news outlets dealing with the topic of sexual harassment since 2017. From 291 registered reports on sexual harassment, collected for the national media monitoring in 2016, the number rose to over 90,000 in 2018. However, within the three-year period of 2016 to 2018 , the majority of reports pertained to incidents which happened abroad, from the 2016 Cologne 
cases to the publicised \#MeToo events of the Global North (SNSL'P 2017, 2018, 2019). Nevertheless, mainstream Slovak media has also gone through some transformation in the past years. Dailies in particular have been employing (women) journalists who have taken charge of the topics of sexual violence and intimate-partner violence, further specialising in what is generally understood as "women's issues" and reporting on violence more sensitively (Valkovičová and Kuruc 2020; German Sirotnikova 2020).

Until 2019, the mainstream national media had been generally more prone to cover news of sexual harassment when it came from abroad. As a country with significant and dominant use of Facebook (instead of Twitter), Slovakia would have been rather closed to the original events, if it was not for the media coverage. The mainstream media such as television and press lacked the national "carriers of the discourse", such as individuals who would be willing to talk about their experience (Valkovičová and Kuruc 2020). In March 2019, Katarína Danová became a public persona after she published a blog and openly spoke to the media about her experience with being groomed and abused as a child (Danová 2019). She was also the first person who in June 2020 complained on her Facebook account about an incident which created a window of opportunity for a national debate on sexual harassment. Katarína Danová alerted her Facebook friends and followers to content aired by TV JOJ, which constituted a possible act of sexual harassment perpetrated by a celebrity and senior actor Maroš Kramár upon a crew member - a (woman) stylist (German Sirotnikova 2020). While the TV channel aired the incident where the actor non-consensually touched the bottom of the stylist as comedic material, the subsequent reaction of two national dailies Denník N and Nový Čas ${ }^{8}$ shamed the actor for his intrusive behaviour, thus to an extent adopting the discourse established by Katarína Danová. While the actor publicly claimed that the incident was a joke since he is friends with the crew member, he also defended himself by mocking the women who would complain about such behaviour. Kramár described the outrage as the agenda of "[f]rustrated women who feel that they have to fight for equality with men" (Gehrerová 2020). The concerned stylist subsequently posted her statement on Instagram, claiming that the actor's behaviour did not harm her and that they were indeed friends. The case led to a wider discussion germinating from articles, blogs and celebrity Facebook statuses (German Sirotnikova 2020). Zuzana Kovačič Hanzelová, a journalist with the daily SME, who had previously reported on stories of harassment and violence, appealed to her Instagram audience to share their stories of harassment with her. She received hundreds of responses (Kovačič Hanzelová 2020). The events eventually led to a special issue of the daily SME on 3 July 2020 in which publicly known women (including the President of Slovakia, Zuzana Čaputová) spoke about their experiences with harassment (German Sirotnikova 2020).

Denouncing the actor's behaviour, the two national dailies were the first to bring this case concerning possible sexual harassment into the public sphere and set a condemning tone,

8 While both Denník N and Nový Čas are widely read print and online dailies, there is a significant difference between their styles and political affiliations. While Denník N keeps to centrist and liberal content within its journalistic diversity of interviews, reports and long-reads, Nový Čas is a tabloid journal mostly seeking sensation and public scandal, with considerable visual content. 
which was not accepted by their entire readership. In order to understand how the readers made sense of the story of potential sexual harassment, and how they deployed trivialising and legitimising narratives of sexual harassment, the following analysis centres on two Facebook posts from June 2020 published by the aforementioned dailies - Denník N (9 June 2020) and Nový Čas (12 June 2020). The analysis looks at both the original comments and the reactions to them $(\mathrm{n}=472)$ as we approached each comment as a unique contribution to the dataset (Clark-Parsons 2020; Bogen et al. 2020). We chose an inductive coding approach towards the comments which was conducted with the aid of Atlas.Ti software. Within the analysis we understood the texts as sites of social struggles in that they manifested traces of differing ideological fights for dominance and hegemony, visible within the present discourses (Reisigl and Wodak 2013). We understand discourses to be institutionalised ways of talking which regulate and reinforce action (Jäger and Maier 2013; Fairclough 2013). What we aim is to discuss what kinds of sexual harassment narratives as arguments are deployed in order to oppose the developing feminist framing of sexual harassment. The study of public discourses via the approach of argumentative analysis is one way of looking into the knowledge production around these topics. By targeting the social media as public arenas, we were able to focus on these discursive events and discursive argumentative strategies based on the "interpretative repertoires" of the discussants (Edley and Wetherell 2001). The next section summarises the results of the analysis.

\section{Results of the Argumentative Analysis}

The results of the analysis can be grouped into clusters of argumentation strategies which provided us with some understanding of how individual discussants reacted to the articles at Denník N and Nový Čas. We were able not only to group the clusters of argumentative strategies from the primarily coded data, but also to make use of the Atlas.Ti "code co-occurrence analysis", which shed some light at the co-occurrence of these strategies.

Some comments did not make it into the analysed dataset, most notably those which could not be assigned a particular code. These were comments which did not contain any argument or information, such as those simply consisting of emojis. ${ }^{9}$ Other comments which could not be included in the dataset involved possible sarcastic reactions (which were excluded due to unreliability) and comments with gifs and memes which were also difficult to decipher due to the multiple possible meanings. A small group of comments under both posts also included verbal abuse $(n=39)$. These comments lacked any interpretative potential for the analysis since they did not contain any argument or position. We believe this to be a major limit of argumentative analysis or any kind of discourse analysis which draws from social media communication. This communication which is based on simplistic symbols (from gifs to "likes") is not easily interpreted, and also significantly biases the results of the analysis, which generally prefers comprehensive verbal statements. Both of the Facebook debates contained such restricted data which means that the results of the analysis could have

9 While we initially contemplated the arduous task of coding emoji comments, these data ultimately proved to be unreliable. 
been drawn only from comments where the discussants displayed an argument and provided enough information for us to grasp the deployed interpretative repertoires. Comments that also lacked potential for the analysis were those coded as "egocentric reactions" $(\mathrm{n}=4)$. These were, for example, comments where the discussants diverted the communication to themselves, as they informed others of their own non-harassing behaviour or about their disinterest in television. The sections below present the argumentative strategies which were deployed by the discussants to legitimise or trivialise sexual harassment in general or in particular with regards to the events of June 2020.

\section{Accusations of Opportunism, Humour and Distraction}

A small number of comments $(n=18)$ generally appearing in the Nový Čas debate questioned the motivations of the stylist, women in general or the TV channel, accusing them of opportunistic behaviour. The discussants accused the channel or show of sensationalism and seeking high viewing rates, while the stylist (and in two other comments, women in general) was accused of seeking publicity: "I hope the lady was not hurt... But yes. This is also the way to make oneself famous... Her name and her pictures are everywhere" (Nový Čas 2020).

Another smaller number of comments $(n=13)$ were either "humourising" sexual harassment by directly using humour to talk about the event or referred to the statements of the actor and the stylist who described the incident as the outcome of a joyous atmosphere: "Yes, this was just some fun among colleagues and that is the level which is understandable and how they meant it. Inkognito [the name of the show] is neither an educational show nor a show about social behaviour. It is a comedy show. Oftentimes they joke about the Roma or the handicapped [...] so I do not understand this hysteria [...]" (Denník N 2020). Despite our expectations, the practice of humourising was not a predominant argumentative strategy among the discussants.

Quite unexpectedly, as many as 113 comments were classified as distracting. A small number of the distracting comments either referred to other Slovak celebrities who engaged in intrusive behaviour, or the comments denounced the TV station or the show for being unsavoury. However, the majority of these comments $(n=79)$ were derogatory towards the actor, generally referring to him as disgusting or rude. These distracting comments branded the actor as an elderly lothario or emphasised the inappropriateness of the behaviour with regards to his age: "Mr. Kramár, your mother must be ashamed of you and so should your children. I mean for your behaviour. You should be aware that as an elderly person you should behave accordingly and that is mainly in public spaces" (Denník N 2020). Initially, while such argumentative strategy may be understood as supportive of the stylist or condemning sexual harassment, the personalisation of the matter in the persona of the actor leads to major simplification. The discussants condemned the incident with the argument of personal distaste, criticising the actor in his position of an elderly man with a childish sense of humour. Such ageist advocacy framed the issue of the (un)desirability of sexual harassment as a matter of the personal characteristics of the perpetrator - as an old man, he is discredited because he should not engage in such (sexualised) behaviour. But would the matter be different if he was 
young and attractive? Personalising as a reactionary argumentative strategy aims to relativise the impact of sexual harassment by discussing who is a less or more desirable perpetrator.

\section{Trivialising, Excessive Political Correctness and Polarising}

The most common code co-occurrences were found between trivialising comments $(\mathrm{n}=75)$, comments calling out the "culture of offense" (excessive political correctness) $(n=25)$ and polarising comments $(\mathrm{n}=33)$.

Comments classified as trivialisation of sexual harassment tended to follow the three most common narratives of the events, but only the first two of these were posted in response to the article at tabloid Nový Čas. The first accused the media of "overblowing" the incident. The second common strategy was to downplay the gravity or impact of the physical act of the actor, e.g.: "Stupid fucking people... stupid fucking media [...] Shame... He did not do anything and now for God's sake they are making this into a brutal affair" (Nový Čas 2020). The third trivialising strategy only appeared in the comments at the daily Denník $\mathrm{N}$, in which discussants recalled the friendly ambiance of the TV crew: "Kramár possibly did not know that he was being filmed... for God's sake they are friends... The discussion about sexual harassment does make sense, but we need to use relevant examples such as in the pub, not this..." (Denník N 2020). In six comments this strategy directly referred to the "private nature" of the relationship, making this a private matter which should not be publicly discussed: "[...] you do not understand that you are pinching into the lives of two strangers who are ok [with it] and you are moralizing and judging them!?” (Denník N 2020).

Co-occurring with trivialising comments were comments coded as rejection of "excessive political correctness". These comments oftentimes used exaggeration, as on one side they downplayed the incident and on the other warned about what the outrage at the incident may lead to: "No one is offended, he did nothing. Unbelievable. If this is sexual harassment, boys do not even leave the house because you will be accused. How did we get here. A decent man is almost a sexual maniac..." (Nový Čas 2020), or "I am very worried about the survival of humanity. When a man will not be able to tell a woman that she is for example pretty, that she has a nice figure, that men cannot sleep because of her, or try to touch her (if he is interested in her)..." (Nový Čas 2020). Nevertheless, some discussants at Denník $\mathrm{N}$ who deployed this strategy of rejecting excessive political correctness did not forget to emphasise that "real sexual harassment" was a serious problem and should be dealt with. Distinguishing between this case and other "actually serious cases" of sexual harassment allowed the discussants to take a socially desirable position. They managed to appear as individuals who disagreed with the framing in the media, but at the same time stood on moral ground by rejecting sexual harassment in general.

What we quite expectedly found was the co-occurrence of comments denouncing excessive political correctness and polarising comments. The argumentative strategy of polarisation occurred in three common versions. Firstly, the discussants argued that the people who complain about such behaviour are women, feminists or liberals who are pushing their political agenda upon others: "This is a tough topic for the sick feminists... I am not into Kramár, but what the sick women are able to produce, how much attention the media are 
giving to this, that is a fuckup" (Denník N 2020). Such a polarising strategy directly referred to women (or feminists) as a politically engaged and fearsome group. But secondly, polarising also occurred when discussants implied that only a certain group of sexually restrained and unattractive women would complain about such behaviour, thus reproducing the explanation of the accused actor: "But he did nothing to her, idiotic puritan [women], leave him alone!" (Nový Čas 2020).

What we see here is the construction of a dichotomy between "good women" who do not mind male intrusive behaviour and do not complain, and "liberal and feminist women" or "sexually restrained/problematic women" who do complain and fight to politicise the matter by acting on their own political agenda (since they are not "normal" anyway). Polarising the debate in such a manner prompts the online community to think of the struggle as a tug-o'-war, one side of which is pulled by an undesirable group of women who could turn the matter into a catastrophe for humanity.

\section{Individualised Responsibility}

Last but definitely not least, a considerable number of discussants asserted the concept of individualised responsibility with regards to sexual harassment in general or concerning this case in particular. The discussants deployed this argumentative strategy in three distinct versions:

- "She did not mind" $(\mathrm{n}=22)$ - many discussants pointed to the public statement of the stylist who asserted that she was not harmed by the actor's behaviour. The discussants used this argument to simply "close the case" or to explain that the incident itself could not have been sexual harassment, since there is no actual complainant.

- "If she minded she would have reacted differently" $(\mathrm{n}=13)$ - other discussants explained that there were other possible ways for her to behave if she minded the behaviour. The discussants suggested that she had the option to complain or to physically attack the actor on the spot: "I am not sure why you are discussing this, if she minded, she could have punched him or filed a criminal complaint" (Nový Čas 2020).

- "She should have reacted to it by complaining or by violence" $(\mathrm{n}=18)$ - these discussants suggested what the stylist should have done instead of staying silent on the spot: "The lady should have punched him in such a manner that he would have bounced off the wall [...]" (Denník N 2020).

While the first two versions of this argumentative strategy are deployed by the discussants to explain why the matter was not serious or why it cannot be labelled sexual harassment, the last strategy asserts the moral judgement of the speaker who condemns the inaction of the stylist. This could be understood as an argumentative strategy rooted in a post-feminist perspective of gender equality as already achieved. This perspective is blind to structural inequalities, disregards the unequal position of the stylist as a dismissible employee, and ignores the gendered stereotypes of male and female sexuality. Since men and women are viewed as already equal, there is no need for collective and political transformations. It is 
now up to the individual (i.e. the stylist) to take responsibility for defending herself and to openly vocalise her sexual agency. If she fails to do so, it is proof that she is not experiencing anything harmful, or she is simply discarded as unfaithful to the achieved ideal of liberated female sexuality. Clad in neoliberal attire, the argumentative strategy of "individualised responsibility" is a more elegant version of "victim-blaming" approaches to sexual violence.

\section{Discussion and Conclusions}

A few days after the Slovak national TV JOJ aired this comedic segment displaying the physically intrusive behaviour of a celebrity actor towards a crew member in June 2020, two dailies printed articles condemning his behaviour which garnered a variety of reactions from their readership. Both of these articles presented "counter-narratives" (Worthington 2020) to conventional victim-blaming and dismissive approaches to sexual harassment (Enderle 2018; Sanyal 2019). In response, the readers and Facebook discussants made arguments trivialising and legitimising sexual harassment aimed at altering the knowledge production surrounding the events and countering the ascending (feminist) narratives. The analysis presented here seeks to discuss the argumentative strategies in the Slovak online environment of the "post \#MeToo era". Our research aims to explain how the creeping transnational (feminist) counternarratives are locally contested.

The argumentative strategies which trivialised and legitimised sexual harassment fell to an extent along the lines of the discursive dichotomy of "the public and the private", but more importantly, recalled the feminist activist motto "the personal is political" (Hansson et al. 2020). The discussants actively debated the questions of whether the situation constituted any problem at all, whether there was any harm done, the nature of the relationship between the two persons, and what the stylist should/could have done in her position. Further, the discussants actively 'privatised' the incident in terms of the persona of the actor or recalled the friendship of the two, relativising the impact of such an act, as well as disregarding the various consequences the stylist could have faced if she wished to complain or seek justice as an employee. When the discussants claimed that the incident should not be discussed publicly since the matter is a private issue between the two persons, they deployed the "don't ask/ don't tell" narrative of trivialising sexual harassment (Bogen et al. 2019). A more elaborate argumentative strategy, which is also based on the logic of privatising, is the strategy of individualised responsibility. By privatising the issue, the discussants dismissed the structural nature of sexual harassment as an oppressive gender-based practice and reinforced the discourse on sexual harassment as an individual issue, a unique occurrence which can be either legitimised, or should be tackled by the one who is affected (see e.g. De Benedictis, Orgad, and Rottenberg 2019).

On the contrary, the argumentative strategies of polarising and rejecting excessive political correctness were intended to "politicise" the matter by describing women who would complain about such intrusive male behaviour as dangerous political agents. These women were described as sexually restrained, abnormal and politically radical - branded as an undesirable and potentially threatening group. In essence, this is a very clear strategy to warn off any women who would want to stray from that path. 
To a certain extent, we can argue that the local trivialising and legitimising argumentative strategies stem from the recent international discursive events of the \#MeToo movement. As a country whose mainstream media has so far generally echoed the international news concerning the events, Slovak online audiences are most likely quite familiar with the changes brought about by the networked communities who managed to advocate and popularise empowering discourses. The "movement" was able to globally produce some achievements reported on by the Slovak media, if we only consider the most discussed results, such as the convictions of celebrity perpetrators. This would explain the fearful reactions of discussants posting polarising comments or rejecting excessive political correctness.

We are certain that the aired incident fell within a "gray area" of intrusive behaviour which could hardly be legally classified as sexual harassment, since there was no complainant. Neither did it initially lead to the hashtag activism of the "transformative politics of visibility" (Clark-Parsons 2019; Suk et al. 2016; Maaranen and Tienari 2020). It nevertheless opened the window of opportunity for some engaged journalists (most notably at the daily SME) who reported on first-person revelations, disclosing the high prevalence and latency of such behaviour, and popularising the survivor-centred and critical narratives of harassment and violence. As witnessed in other countries (see e.g. Mishra 2020), the transnational (feminist) activism did have a belated impact and managed to fuel local advocacy endeavours, once again affirming that "the personal is political".

\section{List of Resources}

Denník N. 2020 (9 June). “Maroš Kramár považuje svoje správanie za „,absolútne vhodné“. ,Je mi l'úto všetkých žien, ktoré som týmto urazil. Ospravedlňujem sa im a fakt mi je l'úto, že sa ich nikto nedotýka", povedal [Maroš Kramár deems his behaviour to be "absolutely appropriate". "I am sorry to all the women I have offended. I apologise to them and I am really sorry that no one touches them", he said]". [Facebook status update]. Retrieved 12 July 2020 (https://www.facebook.com/ projektn.sk/posts/3244492542306949).

Nový Čas. 2020 (12 June). "Herec si poriadne zavaril [The Actor Put His Foot in it]". [Facebook status update]. Retrieved 12 July 2020 (https://www.facebook.com/novycas/posts/3356321704402617).

\section{References}

Adetiba, Elizabeth. 2017. "Tarana Burke Says \#MeToo Should Center Marginalized Communities." The Nation. Retrieved January 6, 2021 (https://www.thenation.com/article/archive/tarana-burkesays-metoo-isnt-just-for-white-people/).

Askanius, Tina and Jannie Møller Hartley. 2019. "Framing Gender Justice: A Comparative Analysis of the Media Coverage of the \#Metoo in Denmark and Sweden." NORDICOM Review 40(2): 19-36.

Berthet, Valentine and Joanna Kantola. 2020. "Gender, Violence, and Political Institutions: Struggles over Sexual Harassment in the European Parliament." Social Politics: International Studies in Gender, State and Society, jxaa015. Retrieved January 6, 2021 (https://academic.oup.com/sp/ advance-article/doi/10.1093/sp/jxaa015/5900431?login=true). 
Bogen, Katherine W. et al. 2019. "\#MeToo: Disclosure and Response to Sexual Victimization on Twitter." Journal of Interpersonal Violence (2019). Retrieved July 12, 2020 (https://journals.sagepub.com/ doi/abs/10.1177/0886260519851211?journalCode=jiva).

Bogen, Katherine W. et al. 2020. "It Happens in \#ChurchToo: Twitter Discourse Regarding Sexual Victimization Within Religious Communities.” Journal of Interpersonal Violence (2020). Retrieved July 12, 2020 (https://journals.sagepub.com/doi/abs/10.1177/0886260520922365?ai=1 gvoiandmi= 3ricysandaf $=\mathrm{R})$.

Burt, Martha R. 1980. "Cultural Myths and Supports for Rape.” Journal of Personality and Social Psychology 38(2): 217-230.

Bútorová, Zuzana et al. 2002. “Ženy, muži a rovnost' príležitostí [Women, Men and Equality of Opportunities].” Pp. 405-442 in Slovensko 2002 - Súhrnná správa o stave spoločnosti II. [Slovakia 2002 - A Comprehensive Report on the State of Society II.], edited by Miroslav Kollár and Grigorij Mesežnikov. Bratislava: Inštitút pre verejné otázky.

Clark, Rosemary. 2016. "'Hope in a Hashtag': The Discursive Activism of \#WhyIStayed.” Feminist Media Studies 16(5): 788-804.

Clark-Parsons, Rosemary. 2019. “'I SEE YOU, I BELIEVE YOU, I STAND WITH YOU': \#MeToo and the Performance of Networked Feminist Visibility." Feminist Media Studies (2019). Retrieved July 12, 2020 (https://www.tandfonline.com/doi/abs/10.1080/14680777.2019.1628797?journalCo $\mathrm{de}=\mathrm{rfms} 20$ ).

Cviková, Jana and Jana Juráňová. 2009. "Niektoré aspekty zrodu rodového diskrzu na Slovensku [Some Aspects on the Birth of Gendered Discourse in Slovakia]." Pp. 7-40 in Feminizmy pre začiatočničky: Aspekty zrodu rodového diskurzu na Slovensku [Feminisms for beginners: Aspects of the birth of gendered discourse in Slovakia], edited by Jana Cviková and Jana Juráňová. Bratislava: ASPEKT.

Danová, Katarína. 2019. "Tento text nie je o otužovaní [This Text is Not about Hardening in Cold Water]." Náš Kurník. Retrieved January 6, 2021 (https://naskurnik.sk/tento-text-nie-je-o-otuzovani/).

De Benedictis, Sara, Shani Orgad, and Catherine Rottenberg. 2019. "\#MeToo, Popular Feminism and the News: A Content Analysis of UK Newspaper Coverage." European Journal of Cultural Studies 22(5-6): 718-738.

Edley, Nigel and Margaret Wetherell. 2001. “Jekyll and Hyde: Men's Constructions of Feminism and Feminists." Feminism and Psychology 11(4): 439-457.

Enderle, Taylor. 2018. "A Rhetorical Analysis of the Public Sphere Through the \#MeToo Movement." Quest: A Journal of Undergraduate Student Research 6(1): 52-68.

Eschle, Catherine and Bice Maiguashca. 2018. "Theorising Feminist Organising in and Against Neoliberalism: Beyond Co-Optation And Resistance?" European Journal of Politics and Gender 1(1-2): 223-239.

Fairclough, Norman. 2013. "A Dialectical-Relational Approach to Critical Discourse Analysis in Social Research.” Pp. 162-186 in Methods of Critical Discourse Analysis, edited by Ruth Wodak and Michael Meyer. London: SAGE Publications Ltd.

Fraser, Nancy. 1990. "Rethinking the Public Sphere: A Contribution to the Critique of Actually Existing Democracy." Social Text 25/26 (1990): 56-80.

Freedman, Estelle. 2018. "Women's Long Battle to Define Rape. In Where Freedom Starts: Sex, Power, Violence (A Verso Report).” Pp. 100-104 in Where Freedom Starts: Sex, Power, Violence, \#MeToo, edited by Verso. New York: Verso.

Gavison, Ruth. 1992. "Feminism and the Public/Private Distinction." Stanford Law Review 45(1): 1-45. Gehrerová, Ria. 2020. "Na čo sme sa pozerali, ked’ Maroš Kramár chytal kolegyňu za zadok [What Were We Watching When Maroš Kramár Grabbed His Colleague by Her Butt].” Denník $N$. Retrieved July 9, 2020 (https://dennikn.sk/1924955/na-co-sme-sa-pozerali-ked-maros- 
kramar-chytal-kolegynu-za-zadok/?fbclid=IwAR0eG1 znogxXb66sS4WyBQ-X2Adz1e96vVQYPGF1SCief2iyyxnmaoPQVw).

German Sirotnikova, Miroslava. 2020. "Slovak Women Journalists Take On Corruption, But Ignore Own Sexual Harassment.” Balkan Insight. Retrieved January 12, 2021 (https://balkaninsight. com/2020/08/21/slovak-women-journalists-take-on-corruption-but-ignore-own-sexualharassment/).

Ghadery, Farnush. 2019. “\#Metoo - Has the 'Sisterhood' Finally Become Global or Just Another Product of Neoliberal Feminism?” Transnational Legal Theory 10(2): 252-274.

Ha Rim Rho, Eugenia, Gloria Mark, and Melissa Mazmanian. 2018. "Fostering Civil Discourse Online: Linguistic Behavior in Comments of the \#MeToo Articles across Political Perspectives." Proceedings of the ACM on Human-Computer Interaction. Retrieved July 12, 2020 (https://dl.acm. org/doi/10.1145/3274416).

Hansson, Karin et al., 2020. "Legitimising a Feminist Agenda - The \#metoo Petitions in Sweden 20172018.” Nordic Journal of Media Studies 2(1). Retrieved January 6, 2021 (https://content.sciendo. $\mathrm{com} /$ view/journals/njms/2/1/article-p121.xml).

Holubová, Barbora. 2007. Sexuálne a šikanózne obt'ažovanie žien na pracovisku [Sexual Harassment and Bullying of Women at Work]. Bratislava: Inštitút pre výskum práce a rodiny.

Holubová, Barbora. 2010. Úloha médii v prevencii násilia páchaného na ženách a v podpore rodovej rovnosti [The Role of Media in Prevention Against Violence Against Women and the Support of Gender Equality]. Bratislava: Inštitút pre výskum práce a rodiny.

Hindes, Sophie and Bianca Fileborn. 2019. “'Girl Power Gone Wrong’: \#MeToo, Aziz Ansari, and Media Reporting of (Gray Area) Sexual Violence.” Feminist Media Studies (2019). Retrieved July 12, 2020 (https:/www.tandfonline.com/doi/abs/10.1080/14680777.2019.1606843).

Jäger, Siegfried and Florentine Maier. 2013. "Theoretical and Methodological Aspects of Foucauldian Critical Discourse Analysis and Dispositive Analysis." Pp. 34-61 in Methods of Critical Discourse Analysis, edited by Ruth Wodak and Michael Meyer. London: SAGE Publications Ltd.

Konrad, Alison M. and Barbara Gutek. 1986. "Impact of Work Experiences and Attitudes Toward Sexual Harassment." Administrative Science Quarterly 31(3): 422-438.

Lonsway, Kimberly, Lilia M. Cortina, and Vicki J. Magley. 2008. "Sexual Harassment Mythology: Definition, Conceptualization, and Measurement." Sex Roles 58: 599-615.

Kovačič Hanzelová, Zuzana. 2020. "Vyslali sme signál obetiam, že majú držat' ústa [We Sent out the Message to Victims that They Should Keep Their Mouths Shut]." Ženy v meste. Retrieved January 6, 2021 (https://www.zenyvmeste.sk/sexualne-obtazovanie-obete-reakcie-svedectvalekari-neurolog).

Lee, Myunghee and Amanda Murdie. 2020. “The Global Diffusion of the \#MeToo Movement." Politics and Gender. Retrieved January 6, 2021 (https://www.cambridge.org/core/journals/politics-andgender/article/abs/global-diffusion-of-the-metoo-movement/9408DE70B7612976E38F77BE2D6 BDB81).

Lockyer, Sharon and Heather Savigny. 2020. "Rape Jokes Aren't Funny: The Mainstreaming of Rape Jokes in Contemporary Newspaper Discourse." Feminist Media Studies 20(3): 434-449.

Maaranen, Anna and Janne Tienari. 2020. "Social Media and Hyper-Masculine Work Cultures." Gender, Work and Organization (2020). Retrieved July 12, 2020 (https://onlinelibrary.wiley.com/doi/ full/10.1111/gwao.12450).

MacKinnon, Catharine. 1979. The Sexual Harassment of Working Women. New Haven, CT: Yale University Press.

Magurová, Zuzana. 2008. "Sexuálne obt’ažovanie [Sexual Harassment]." Diskriminacia.sk. Retrieved July 12, 2020 (http://diskriminacia.sk/zuzana-magurova-sexualne-obtazovanie/). 
Malovich, Natalie J. and Jayane E. Stake. 1990. "Sexual Harassment on Campus - Individual Differences in Attitudes and Beliefs." Psychology of Women Quarterly 14(1990): 63-81.

McCabe, Marita P. and Lisa Hardman. 2010. "Attitudes and Perceptions of Workers to Sexual Harassment." The Journal of Social Psychology 145(6): 719-740.

McDonald, Paula. 2012. "Workplace Sexual Harassment 30 Years on: A Review of the Literature." International Journal of Management Reviews 14(2012): 1-17.

Mishra, Suman. 2020. "From \#MeToo to \#MeTooIndia: News Domestication in Indian English Language Newspapers." Journalism Studies 21(5): 659-677.

Reese, Hope and Stephanie Coontz. 2018. "\#MeToo is Powerful But Will Fail Unless We Do More." Pp. 19-25 Where Freedom Starts: Sex, Power, Violence, \#MeToo, edited by Verso. New York: Verso.

Reisigl, Martin and Ruth Wodak. 2013. "The Discourse-Historical Approach (DHA)." Pp. 87-121 in Methods of Critical Discourse Analysis, edited by Ruth Wodak and Michael Meyer. London: SAGE Publications Ltd.

Rihal, Charanjit S. et al., 2020. "Addressing Sexual Harassment in the \#MeToo Era: An Institutional Approach.” Mayo Clinic Proceedings 95(4): 749-757.

Rhode, Deborah L. 1995. "Media Images, Feminist Issues.” Signs 20(3): 685-710.

Rothgerber, Hank et al. 2020. "Is Reasonable Woman Different from a Reasonable Person? Gender Differences in Perceived Sexual Harassment." Sex Roles (2020). Retrieved July 12, 2020 (https:// www.scilit.net/article/670670d191 ef8cfa821fbd27ff8ce704).

Russell, Brenda L. and Kristin Y. Trigg. 2004. "Tolerance of Sexual Harassment: An Examination of Gender Differences, Ambivalent Sexism, Social Dominance, and Gender Roles." Sex Roles 50(7-8): 565-573.

Sanyal, Mithu. 2019. Rape: From Lucretia to \#MeToo. New York: Verso.

Slovenské národné stredisko pre l'udské práva (SNSL'P). 2017. Monitoring prípadov sexuálneho obtažovania a šikanovania žien na pracovisku za rok 2016 [Monitoring of Cases of Sexual Harassment and Bullying of Women at Work for 2016]. Retrieved January 6, 2021 (http://www. snslp.sk/CCMS/files/Monitoring_pripadov_sexualneho_obtazovania_2016_FINAL.pdf).

Slovenské národné stredisko pre l'udské práva (SNSLP). 2018. Monitoring prípadov sexuálneho obt’ažovania a šikanovania žien na pracovisku za rok 2017 [Monitoring of Cases of Sexual Harassment and Bullying of Women at Work for 2017]. Retrieved January 6, 2021 (http://www. snslp.sk/CCMS/files/Monitoring_sexualne_obtz_a_sikana_na_pracovisku_2017.pdf).

Slovenské národné stredisko pre l'udské práva (SNSLP). 2019. Monitoring prípadov sexuálneho obt’ažovania a šikanovania žien na pracovisku za rok 2018 [Monitoring of Cases of Sexual Harassment and Bullying of Women at Work for 2018]. Retrieved January 6, 2021 (http://www. snslp.sk/CCMS/files/Monitoring_sexu\%C3\%A1lneho_ob\%C5\%A5a\%C5\%BEovania_\%C5\%BE ien_2018.pdf).

Suk, Jiyoun et al. 2019. "\#MeToo, Networked Acknowledgement, and Connective Action: How 'Empowerment Through Empathy' Launched a Social Movement.” Social Science Computer Review (2019). Retrieved July 12, 2020 (https://journals.sagepub.com/doi/10.1177/0894439319864882).

Truman, Dana M., David Tokar, and Ann Fischer. 1996. "Dimensions of Masculinity: Relations to Date Rape Supportive Attitudes and Sexual Aggression." Journal of Counseling and Development 74(6): $555-562$.

Ullman, Sarah E. 2000. "Psychometric Characteristics of the Social Reactions Questionnaire: A Measure of Reactions to Sexual Assault Victims." Psychology of Women Quarterly 24(3): 257-271.

Valkovičová, Veronika and Andrej Kuruc. 2020. Nástroje na prevenciu sexuálneho obtažovania ako formy rodovej diskriminácie [Tools for Prevention of Sexual Harassment as a Form of Gender Discrimination]. Bratislava: Inštitút pre výskum práce a rodiny. 
Vera-Gray, Fiona. 2017. Men 's Intrusion, Women's Embodiment: A Critical Analysis of Street Harassment. London: Routledge.

Walby, Sylvia. 1990. Theorizing Patriarchy. Hoboken, New Jersey: Blackwell Publishers.

Worthington, Nancy. 2020. "Celebrity-Bashing or \#MeToo Contribution? New York Times Online Readers Debate the Boundaries of Hashtag Feminism." The Communication Review 23(1): 46-65.

\section{Author}

Veronika Valkovičová is a post-doc researcher at the Faculty of Social Sciences - University of Antwerp (Belgium) and an analyst at the Institute for Family and Labor Research in Bratislava (Slovakia). Her research focuses on feminist and women's rights social movements, and public policies tackling (gender) inequalities.

Contact: valk.veron@gmail.com 